\title{
Wynagrodzenia i wydajność pracy w rolnictwie polskim na tle pozostałych krajów Unii Europejskiej
}

\section{Wstęp}

Poprawa ekonomicznej wydajności pracy ${ }^{1}$ determinuje wyższy poziom dobrobytu społeczeństwa (bogactwa konsumentów). Przyczynia się do tego przede wszystkim poprawa technicznego uzbrojenia pracy oraz poprawa jej organizacji. Optimum producenta wyznacza punkt zrównania się wynagrodzenia danego czynnika z jego produktywnością (wydajnościa) krańcową. Dopuszczalne wynagrodzenie pracy określa przychód krańcowy tego czynnika produkcji lub jego koszt krańcowy [Rembisz 2013]. Między czynnikami produkcji istnieje ścisła współzależność, gdyż ich wielkości harmonicznie dopasowują się w procesie gospodarczym.

Wydajność pracy wiąże się z optymalnym wykorzystaniem zasobów gospodarstwa rolnego, które determinuje zarówno konkurencyjność poszczególnych gospodarstw rolnych, jak również całego sektora na europejskim oraz światowym rynku [Mrówczyńska-Kamińska 2012]. Niewatpliwie, wydajność pracy w rolnictwie zależy od jej technicznego uzbrojenia oraz od wielkości areału użytków rolnych (UR) przypadającego na zatrudnionego [Czyżewski, Kryszak 2016, Kusz, Misiak 2017]. Redukcja obecnego poziomu zatrudnienia (która stopniowo

\footnotetext{
${ }^{1}$ Wyróżnia się społeczną, ekonomiczną oraz techniczną wydajność pracy.
} 
zachodzi ${ }^{2}$ ), zwiększanie powierzchni gospodarstw rolnych i w efekcie skali produkcji (również powoli zachodzą) oraz wzrost nakładów kapitału to założenia konieczne dla dalszego rozwoju sektora rolnego. Dopiero one pozwolą osiagnąć trwałą i stabilną poprawę wydajności pracy, a co za tym idzie, również wynagrodzeń rolników [Gadomski 2015].

Najwyższy udział aktywnych zawodowo w rolnictwie wśród państw Unii Europejskiej (UE) w ogólnej liczbie ludności wykazują Polska (ok. 10\%) i Grecja (ok. 6\%). Dane te świadczą o dużym dystansie dzielącym Polskę od pozostałych państw Unii Europejskiej, gdzie udział ten często oscyluje wokół 1-2\% (Holandia, Belgia, Dania).

Celem niniejszej pracy jest analiza relacji między wynagrodzeniem pracy (dostępne dane dotyczą pracowników najemnych, niemniej jednak pozwalają nakreślić ogólne tendencje) a jej wydajnością w krajach Unii Europejskiej (UE), jak również ocena zróżnicowania tych wielkości wewnątrz Wspólnoty. Na podstawie danych liczbowych Eurostatu pokazano aktualne relacje tych wartości oraz ich zmienność w czasie. Dane empiryczne odniesiono do teoretycznych założeń (relacji wzorcowych - por. założenia analityczne). Celem była również weryfikacja wyników badań własnych w odniesieniu do teorii oraz dorobku innych autorów.

\section{Odniesienie do literatury}

Wskazuje się, że wydajność pracy to jeden z najważniejszych elementów decydujących o poziomie efektywności produkcji w rolnictwie. Zdeterminowana jest ona przez zespół czynników, takich jak struktura agrarna rolnictwa, liczba pracujących w rolnictwie i ich poziom przygotowania zawodowego, organizacja pracy, a przede wszystkim poprzez postęp techniczny. Poziom zaawansowania technicznego rolnictwa decyduje m.in. o poziomie technicznego uzbrojenia pracy. $\mathrm{Z}$ reguły niska wartość technicznego uzbrojenia pracy niekorzystnie wpływa na efektywność wykorzystania siły roboczej [Gołaś, Kozera 2008, Nowak 2011].

\footnotetext{
${ }^{2}$ Wraz z rozwojem gospodarczym maleje znaczenie rolnictwa w gospodarce narodowej, w zatrudnieniu, a także w kreowaniu produktu krajowego brutto (takie procesy mają miejsce w Polsce). Nowoczesny sektor rolny coraz silnej staje się powiązany z innymi działami gospodarki narodowej. Obecnie tylko $10 \%$ mieszkańców wsi utrzymuje się jedynie z rolnictwa. Stanowi to zarazem około 10\% całego społeczeństwa [Góral 2017]. Badania J. Wąsowicza [2013] pokazują, że spadek zatrudnienia $\mathrm{w}$ rolnictwie o blisko $18 \%$ przyczynił się do wzrostu wydajności pracy o 8\% (w latach 2004-2011).

${ }^{3} \mathrm{Z}$ danych GUS wynika, że maleje liczba gospodarstw najmniejszych, wzrasta zaś liczba gospodarstw o areale powyżej 15 ha oraz powyżej 100 ha UR. Wzrosła średnia powierzchnia gospodarstwa rolnego z 9,91 ha w 2007 roku do 10,65 ha w 2017 roku [GUS, ARiMR 2017].
} 
Wartość dodana jest jedną z najbardziej zobiektywizowanych kategorii oceny efektywności przedsiębiorstw stosowaną w ocenie wydajności pracy. Jej istota wynika $\mathrm{z}$ tego, że mierzy ona wydajność pod kątem widzenia wartości wnoszonych przez kapitał ludzki w stosunku do kosztów materialnych pochodzących z zewnątrz. Stanowi ważne kryterium zdolności generowania wartości dla właścicieli [Gołaś 2010a].

$\mathrm{W}$ artykule przyjęto, że wynagrodzenie czynnika pracy jest zgodne z wartością dodana, jaką wnosi do całej wartości produktu, czyli z jego produktywnością [Clark 1899]. Poziom wynagrodzenia, zgodnie z podejściem tegoż autora i przyjętym poglądem w mikroekonomii, określony jest przez produktywność krańcową czynnika, co wynika z warunków równowagi producenta. Relacja wynagrodzenia do wydajności nie powinna być większa od jedności (lub 100\%). Relacja wynagrodzenia do jego źródła sfinansowania jest istotą teorii jednostkowych kosztów pracy (Unit Labour Costs), powszechnie wykorzystywanego miernika w pracach OECD, czy Banku Światowego.

Jednak wysokość wynagrodzeñ ${ }^{4}$ to zmienna zależna od wielu czynników egzogenicznych, wśród których kluczowe znaczenie ma poziom rozwoju gospodarczego danego kraju. Wraz z rozwojem gospodarczym relatywny udział sektorów o niskiej wartości dodanej (np. rolnictwa) powinien maleć. Przepływ siły roboczej z sektorów o niskiej wydajności pracy do pozostałych (właściwa alokacja siły roboczej) stanowi jeden z istotnych czynników wpływających na dynamikę przeciętnej wydajności pracy oraz tempo wzrostu gospodarczego [Kosmalski 2010, Dąbrowska 2017].

W 2016 roku wartość PKB wytworzonego w ciagu jednej przepracowanej godziny (miara produktywności technicznej, którą posługuje się OECD) dla Polski wyniosła 32 USD (wartość w cenach bieżących, zgodnie z parytetem siły nabywczej). W tym samym czasie średnia dla krajów UE wyniosła 53,6 USD, a dla krajów strefy euro 59,8 USD. Luksemburg mógł pochwalić się wartością przeszło trzykrotnie wyższą od naszej, czyli 97,5 USD [Dą̧browska 2017]. Na rysunku 1 zobrazowano to niekorzystne dla Polski zestawienie. Warto dodać, że do takiej sytuacji w dużej mierze przyczynia się polski sektor rolny, w którym wydajność pracy jest najniższa w porównaniu do innych sektorów w całej gospodarce. W 2016 roku w rolnictwie pracowało 10,6\% wszystkich osób zatrudnionych w polskiej gospodarce, ale wytwarzały one zaledwie $2,4 \%$ jej wartości dodanej.

\footnotetext{
${ }^{4}$ Kategoria wynagrodzeń dotyczy ograniczonej grupy osób w rolnictwie, ponieważ właściciele gospodarstw rolniczych uzyskują $\mathrm{z}$ racji pracy $\mathrm{w}$ gospodarstwie dochód $\mathrm{z}$ rodzinnego gospodarstwa rolnego, który stanowi zarówno opłatę za zaangażowanie własnych czynników produkcji w działalności operacyjnej gospodarstwa rolniczego (w tym również opłatę za wykonaną prace), ale także za ryzyko podejmowane przez prowadzącego to gospodarstwo [Zegar 2008, Wasilewski, Wasilewska 2011].
} 


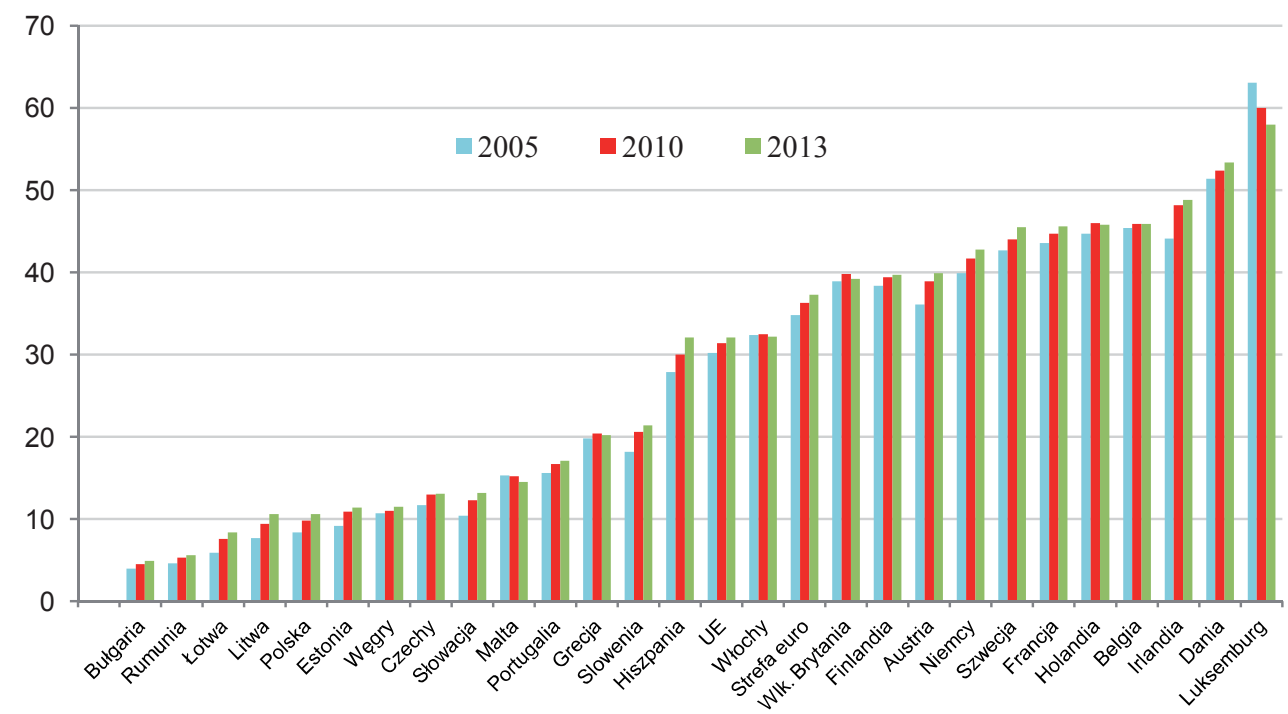

\section{Rysunek 1}

Wydajność pracy (PKB na roboczogodzinę w gospodarce) w euro

Źródło: https://www.obserwatorfinansowy.pl/tematyka/makroekonomia/najpierw-wydajnosc-potem-wynagrodzenia/ (dostęp: 30.08.2017)

To wyraźnie pokazuje, jak niska jest ich wydajność pracy. Jeszcze gorzej polskie rolnictwo wypada na tle rolnictwa unijnego, co zostało przedstawione w dalszej części pracy ${ }^{5}$.

$\mathrm{Z}$ analiz porównawczych prowadzonych przez W. Pocztę i M. Kołodziejczak [2004, 2008], M. Kołodziejczak i A Mrówczyńska-Kamińska [2008] oraz M. Kołodziejczak [2008a, 2014] wynika, że najwyższą wydajność pracy w rolnictwie osiągały państwa północno-zachodniej UE (Wielka Brytania, Francja, Holandia, Dania), najniższą - Polska, Litwa i Węgry.

Polska wypada niekorzystnie na tle Unii Europejskiej, gdy porówna się poziom nakładów pracy w rolnictwie (AWU) w przeliczeniu na powierzchnię użytków rolnych (np. 100 ha). Średnia wartość tego wskaźnika w Unii Europejskiej kształtuje się na poziomie 6 AWU na 100 ha użytków rolnych. W Polsce jest ona dwukrotnie większa ${ }^{6}$. W Wielkiej Brytanii czy Danii oscyluje natomiast jedynie wokół 2 AWU na 100 ha. Te niekorzystne statystyki powoli ulegają poprawie, o czym świadczą dane zawarte w tabeli 1.

\footnotetext{
${ }^{5}$ Należy jednak zaznaczyć, że w Polsce funkcjonuje bardzo dużo drobnych gospodarstw nieprodukujących na rynek, czyli nietowarowych (tzw. socjalnych). Jest to zjawisko dalece odmienne od struktury rolnictwa państw Zachodniej Europy (Francji, Niemiec, Holandi czy Danii).

${ }^{6}$ Należy dodać, że w porównaniu z UE, w polskim rolnictwie jest największy odsetek gospodarstw prowadzonych przez osoby do 35 . roku życia i wynosi on około $15 \%$ przy średniej unijnej na poziomie nieco ponad $6 \%$.
} 
Tabela 1

Tendencje zmian w zakresie nakładów pracy (w AWU, $2005=100)$

\begin{tabular}{|c|c|c|c|c|}
\hline Wyszczególnienie & 2000 & $2005=100$ & 2010 & 2015 \\
\hline UE-27 & 121 & 100 & 78 & 69 \\
\hline UE-15 & 113 & 100 & 87 & 78 \\
\hline Polska & 108 & 100 & 83 & 84 \\
\hline
\end{tabular}

Źródło: Eurostat, http://ec.europa.eu/eurostat/data/database (dostęp: 29.08.2017)

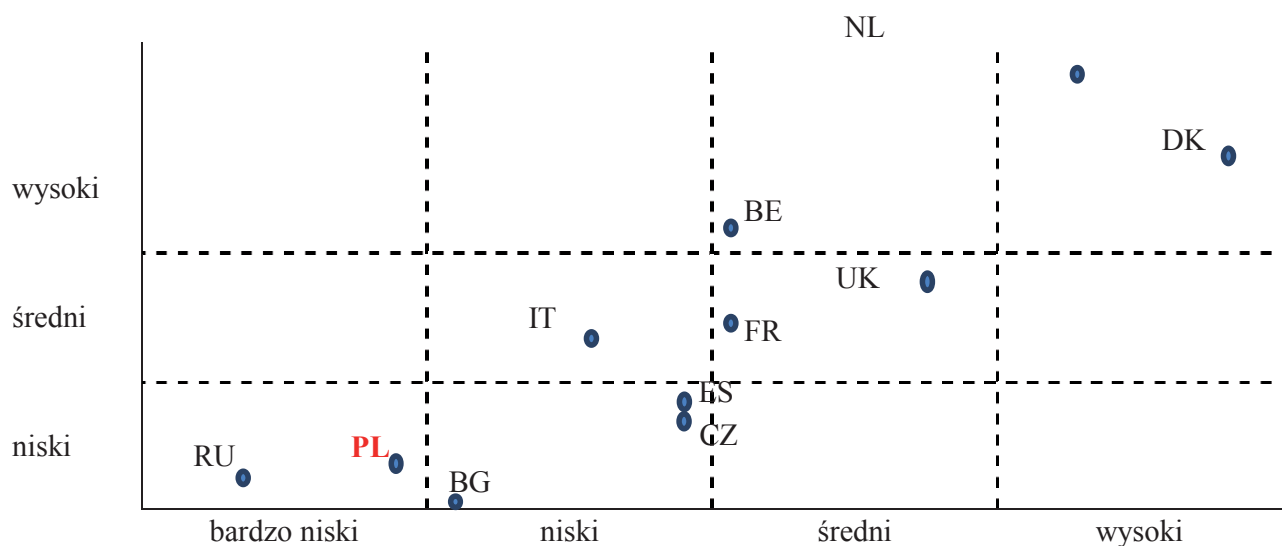

Objaśnienia: na osi OX przedstawiono syntetyczny miernik relacji między czynnikami produkcji, a na osi OY syntetyczny miernik produktywności czynników produkcji (ziemi i pracy). PL - Polska, RU - Rumunia, BG - Bułgaria, IT - Włochy, FR - Francja, ES- Hiszpania, CZ - Czechy, UK - Wielka Brytania, BE - Belgia, DK - Dania, NL - Holandia.

\section{Rysunek 2}

Typologia wybranych państw UE ze względu na mierniki syntetyczne relacji między czynnikami produkcji oraz ich efektywności

Źródło: Opracowanie na podstawie Bear-Nawrocka i Markiewicz [2013].

Na rysunku 2 pokazano, jak niekorzystne są relacje między wszystkimi czynnikami produkcji w polskim rolnictwie oraz jak negatywne skutki to za sobą niesie (małe efekty) w porównaniu do wyników innych państw [Bear-Nawrocka i Markiewicz 2013, Duczkowska-Małysz 2015].

Z danych publikacji pt. „Raport o stanie wsi. Polska wieś 2016” [Nużyńska, Wilkin 2016] wynika, że polskie rolnictwo dysponuje około 8\% zasobów ziemi, $20 \%$ nakładów pracy oraz 5\% nakładów kapitału całej UE-28. Powierzchnia UR na 1 AWU wynosi jedynie 7,4 ha i jest większa zaledwie od maltańskiej, cypryjskiej oraz słoweńskiej. Nakłady kapitału na 1 AWU stanowiły tylko 20-25\% średniej unijnej i były najniższe w UE. Relacje obrazujące wyposażenie pracy w pozostałe dwa czynniki produkcji (ziemię i kapitał) wskazują na słabą kon- 
kurencyjność polskiego sektora rolnego w zakresie potencjału produkcyjnego i determinują niską wydajność pracy. Ponadto, polskie rolnictwo pod względem waloryzacji rolniczej przestrzeni produkcyjnej zajmuje jedną z ostatnich pozycji w Europie. Użytki rolne w Polsce są słabej jakości, gdyż wskaźnik bonitacji gleb wynosi średnio 0,82 . Gleby bardzo dobre i dobre stanowią jedynie $11,5 \%$ całości UR [Nowak 2011].

Reasumując, w polskim rolnictwie poziom wydajności pracy jest bardzo niski w porównaniu do innych państw UE [Maciejewicz 2016]. Powoli uwidaczniają się jednak pozytywne zmiany [Wąsowicz 2013], zachodzące na skutek spadku zatrudnienia w rolnictwie przy jednoczesnym utrzymaniu, a nawet wzroście poziomu produkcji.

\section{Założenia analityczne}

Kwestia relacji wynagrodzenia i wydajności czynnika pracy wynika z teorii równowagi producenta oraz stref racjonalności w analizie funkcji produkcji [Debertin 1986]. Producent rolny, podobnie jak każdy inny, powinien równoważyć poziom wynagrodzenia z produktywnością każdego z zaangażowanych czynników produkcji. W szczególności poziom wynagrodzenia pracy wynikać powinien z produktywności tego czynnika. Zależności te są powszechnie znane z mikroekonomii [Rembisz, Sielska 2015], jak również z analizy funkcji produkcji rolniczej [Debertin 1986].

Przyjmując za podstawę teoretyczną funkcję produkcji rolniczej w postaci ogólnej:

$$
y=f(K, L, Z) \rightarrow \max
$$

oraz wprowadzając elementy równowagi producenta (stąd i wynagrodzenia czynników), jak również dane ceny produktów, otrzymujemy:

$$
R=y \cdot p_{y} \rightarrow \max
$$

przy:

$$
K \cdot c_{K}+L \cdot c_{L}+Z \cdot c_{L}=m^{k} \text { oraz } \Pi=R-m^{k}
$$

gdzie:

$R$ - przychód,

$y \quad$ - wielkość produkcji,

$p_{Y}$ - cena otrzymywana,

$K$ - nakłady czynnika kapitału wraz z ziemią rolna,

$c_{K}$ - wynagrodzenie czynnika kapitału (stopa procentowa i renta), 
$L$ - nakłady czynnika pracy,

$c_{L}$ - wynagrodzenie pracy,

Z - nakłady czynnika ziemia,

$c_{Z}$ - wynagrodzenie czynnika ziemia (renta gruntowa),

$\Pi$ - zysk (dochód producenta rolnego),

$m^{k}$ - ograniczenie finansowe (środki na wynagrodzenia czynników produkcji).

Pomijając szczegółowe przekształcenia i założenia [Rembisz, Sielska 2012], względem maksymalizacji tak ujętej funkcji ${ }^{7}$, mamy proste warunki wyznaczające strefę racjonalności gospodarowania producenta, biorąc pod uwagę jedynie czynnik pracy ${ }^{8}$ :

$$
\frac{y}{L}=\frac{\partial y}{\partial L}=C_{L} \text { oraz } \frac{y}{L} \approx \sim C_{L}
$$

Ta relacja wyznacza dopuszczalny poziom wynagrodzenia czynnika pracy, zakładając dodatnie wartości wydajności krańcowych ${ }^{9}$. Tę drugą relację wykorzystano w analizie empirycznej. Dalej istotne jest to, co określa poziom wynagrodzenia, czyli wydajność czynnika pracy. Wracając do postaci ogólnej, wyjściowej funkcji produkcji można zapisać ją w formie intensywnej, w nawiązaniu do powyższych wzorów:

$$
\frac{y}{L}=f\left(\frac{K}{L}, \frac{Z}{L}\right) \rightarrow \max
$$

oraz rozdzielnie:

$$
\frac{y}{L} \approx \frac{K}{L} \text { oraz } \frac{y}{L} \approx \frac{Z}{L}
$$

jako teoretyczne podstawy czynnika objaśniającego poziom wydajności pracy. Te formuły będą podstawą dalszej analizy empirycznej.

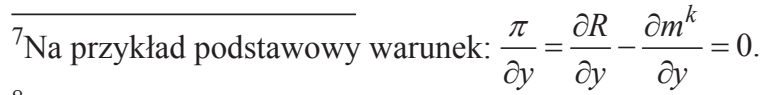

${ }^{8} \mathrm{~W}$ istocie winna tu być funkcja: $y=f(L) \rightarrow \max$.

${ }^{9} \mathrm{~W}$ istocie, odnosząc do pracy najemnej, wysokość wynagrodzenia może być niższa od wydajności krańcowej $\frac{y}{L}>\frac{\partial y}{\partial L}-C_{L}$, gdzie tworzą się zyski nadzwyczajne, ale te sytuacje tu wykluczyliśmy, przyjmując warunki, jak we wcześniejszych odnośnikach.
} 


\section{Założenia metodyczne}

Zróżnicowanie wydajności czynnika pracy oraz jej wynagradzania, według powyższego ujęcia analitycznego, zweryfikowano na podstawie prostej statystyki, jaką jest współczynnik Giniego. Jest on powszechnie stosowaną miarą nierówności rozkładu zmiennych (wielkości), najczęściej dochodów. Podczas jego szacowania bazuje się na funkcji Lorenza (czarna wykropkowana linia na rysunku 3), która obrazuje fakt występowania lub braku występowania nierówności (tu: zróżnicowania wydajności i wynagrodzeń). Współczynnik Giniego zawiera się w przedziale (0-1). Im wyższa jest jego wartość (1), tym większy jest stopień koncentracji zmiennej (u nas: wydajności pracy i wynagrodzeń), a tym samym większe nierówności i zróżnicowanie.

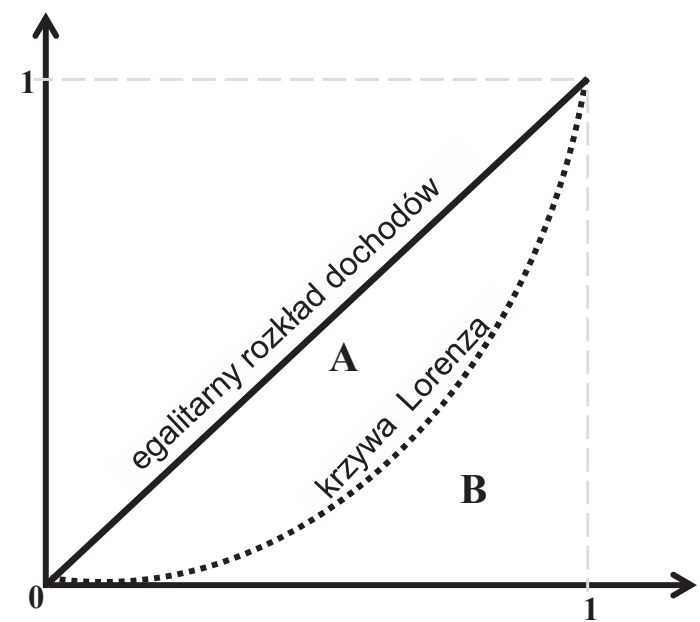

* Linia zielona obrazuje egalitarny rozkład dochodów, a linia czerwona - rozkład nieegalitarny, czyli zróżnicowanie. Im większe odchylenie od rozkładu egalitarnego (większy obszar A), tym większe zróżnicowanie badanej zmiennej i wyższa wartość współczynnika Giniego.

\section{Rysunek 3}

Funkcja Lorenza* oraz interpretacja graficzna współczynnika Giniego Źródło: Opracowanie własne na podstawie [Kakwani 1980].

Im większy obszar A, tym większa jest nierówność. Wynika to z relacji wyznaczającej współczynnik Giniego:

$$
G=\frac{A}{A+B}
$$


Graficzną interpretację wartości współczynnika Giniego można przedstawić jako stosunek pola zawartego między czarną linią równości obrazującą egalitarny rozkład dochodów (in. przekątną na rysunku 3) a wykropkowaną czarną funkcją Lorenza (obszar A) do pola trójkąta pod przekątną $(A+B)$. Współczynnik Giniego jest wielkością znormalizowaną, co ułatwia dokonywanie porównań zarówno w czasie, jak i między różnymi krajami czy populacjami [Włodarczyk 2013].

W naszym przypadku analizujemy zróżnicowanie wydajności pracy oraz wynagrodzania za nią pracowników najemnych w ujęciu międzynarodowym (na poziomie UE). Sposób prezentacji wyników nawiązuje do podejścia zastosowanego przez S. Kuźmara [2015], który wydał się autorom bardzo trafny i czytelny.

\section{Zróżnicowanie wydajności i wynagrodzenia pracy}

Ludność aktywna zawodowo w rolnictwie w UE stanowiła 2,6\% ogółu ludności w 2005 roku, z kolei w 2014 roku udział ten zmalał do 1,9\% [GUS 2016]. Największe zmiany dotyczące redukcji zatrudnionych $\mathrm{w}$ rolnictwie odnotowano w Rumunii (spadek o 2,1\% - z 5,4\% w 2005 roku do 3,3\% w 2014 r.), w Polsce (spadek o 1,9\%), we Francji $(-1,7 \%)$ i na Litwie $(-1,4 \%)$.

Na podstawie danych Eurostatu oraz GUS oszacowano współczynniki Giniego dotyczące wydajności pracy oraz wynagrodzeń w rolnictwie państw UE dla poszczególnych lat z przedziału 2005-2016. Wyniki zestawiono w tabelach 2-5 oraz zobrazowano na rysunkach 4-7. Wielkości zebrane w tabeli 2 świadczą o istotnym zróżnicowaniu w zakresie wydajności pracy, zwłaszcza bardzo dobrze obrazują to wartości współczynnika zmienności.

Co więcej, nierówności w zakresie wydajności pogłębiają się z upływem czasu, szczególnie widoczne to jest od 2011 roku. Co gorsze, w ostatnich latach analizy (2014-2016) najniższą wydajność pracy osiągano właśnie w polskim rolnictwie ${ }^{10}$. Wcześniej, najgorsze wyniki miała w tym zakresie Łotwa (por. tab. 6). Krzywa Lorenza na rysunku 4 także obrazuje fakt występowania dużych nierówności analizowanej zmiennej. Krzywa ta znacznie odchyla się od linii egalitarnej, co świadczy o znacznym zróżnicowaniu.

\footnotetext{
${ }^{10}$ Przykładowo: w 2005 roku największą wydajność pracy w rolnictwie odnotowano w Danii (60,2 tys. euro na 1 AWU), a najmniejszą na Łotwie - 1,9 tys. euro/AWU. W 2010 roku Holandia przodowała w wydajności pracy w rolnictwie (64,3 tys. euro/AWU), a Łotwa (2,8 tys. euro/AWU) znajdowała się na ostatnim miejscu w UE.
} 
Tabela 2

Zróżnicowanie wydajności pracy (wartości dodanej brutto na zatrudnionego) w rolnictwie krajów UE w latach 2005-2016

\begin{tabular}{|c|c|c|}
\hline Lata & Współczynnik Giniego & Współczynnik zmienności [\%] $^{*}$ \\
\hline 2005 & 0,479 & 95,2 \\
\hline 2006 & 0,475 & 93,7 \\
\hline 2007 & 0,474 & 92,1 \\
\hline 2008 & 0,450 & 86,6 \\
\hline 2009 & 0,455 & 90,3 \\
\hline 2010 & 0,443 & 87,0 \\
\hline 2011 & 0,436 & 84,4 \\
\hline 2012 & 0,451 & 88,4 \\
\hline 2013 & 0,441 & 89,5 \\
\hline 2014 & 0,469 & 104,5 \\
\hline 2015 & 0,513 & 133,9 \\
\hline 2016 & 0,495 & 121,7 \\
\hline
\end{tabular}

*Współczynnik zmienności (V) to miara rozproszenia (dyspersji). Jest ilorazem zmienności danej cechy - odchylenia standardowego i średniej wartości tej cechy. Najczęściej wyrażany w procentach. Interpretacja współczynnika zmienności jest następująca: (1) V $<50 \%$ - mała zmienność; (2) $50 \%<V<100 \%$ - umiarkowana zmienność; (3) $V>100 \%$ - duża zmienność. Źródło: Obliczenia własne na danych Eurostatu i GUS.

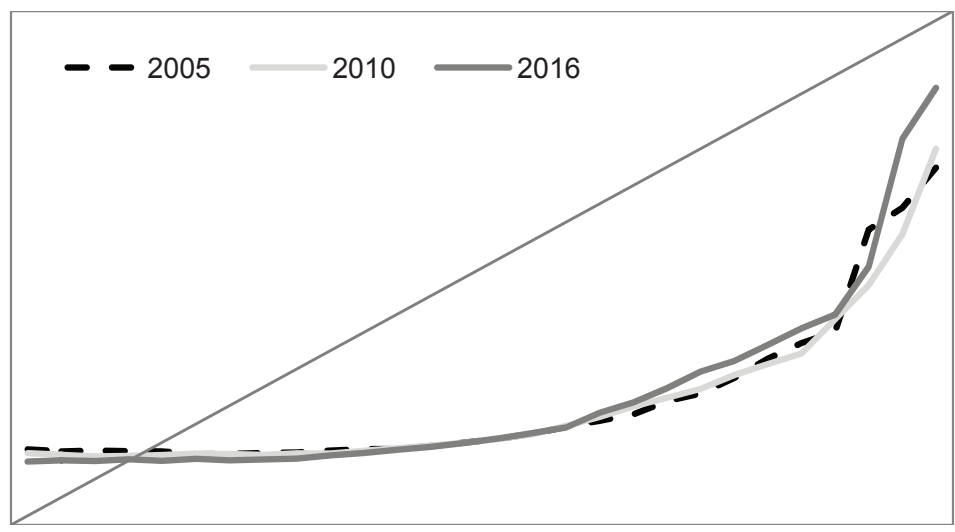

\section{Rysunek 4}

Zróżnicowanie wydajności pracy (wartości dodanej brutto na zatrudnionego) na poziomie UE - interpretacja graficzna współczynników Giniego

Źródło: Opracowanie własne.

W ślad za zróżnicowaniem wydajności czynnika pracy w rolnictwie państw UE poszło, nieco łagodniejsze, zróżnicowanie rozkładu wynagrodzenia pracy. Obliczenia obrazujące tę różnorodność pokazano w tabeli 3 oraz na rysunku 5. 
Tabela 3

Zróżnicowanie wynagrodzenia w rolnictwie w państwach UE

\begin{tabular}{|c|c|c|}
\hline Lata & Współczynnik Giniego & Współczynnik zmienności [\%] \\
\hline 2005 & 0,489 & 97,2 \\
\hline 2006 & 0,478 & 94,0 \\
\hline 2007 & 0,473 & 95,1 \\
\hline 2008 & 0,467 & 93,0 \\
\hline 2009 & 0,468 & 91,8 \\
\hline 2010 & 0,473 & 94,6 \\
\hline 2011 & 0,485 & 97,4 \\
\hline 2012 & 0,489 & 98,2 \\
\hline 2013 & 0,490 & 98,0 \\
\hline 2014 & 0,482 & 96,4 \\
\hline 2015 & 0,478 & 94,5 \\
\hline 2016 & 0,469 & 92,1 \\
\hline
\end{tabular}

Źródło: Obliczenia własne na danych Eurostatu i GUS.

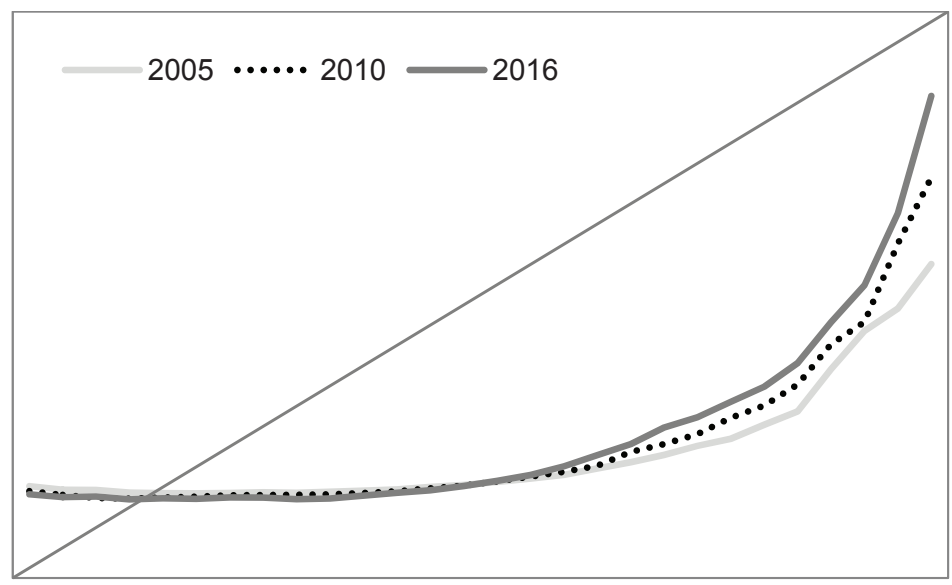

\section{Rysunek 5}

Krzywe Lorenza ilustrujące zróżnicowanie wynagrodzeń w rolnictwie UE - interpretacja graficzna współczynników Giniego

Źródło: Opracowanie własne.

Na rysunku 5 również współczynnik zmienności świadczy o dużych rozbieżnościach w poziomie wynagrodzeń w rolnictwie Wspólnoty. Potwierdza to również charakter krzywej Lorenza i duży „obszar A” na rysunku 5.

Warto dodać, że przez cały analizowany okres (2005-2016) niezmiennie najwyższe wynagrodzenie otrzymywali rolnicy szwedzcy (17,2-30,4 tys. euro), a najniższe w bułgarscy $(0,2-0,6$ tys. euro) i rumuńscy $(0,5-0,9$ tys. euro rocznie) . 


\section{Zróżnicowanie uwarunkowań wydajności pracy}

W tym miejscu dokonano analizy czynników determinujących wydajność pracy, zgodnie z przyjętym ujęciem analitycznym. Oszacowano zróżnicowanie uzbrojenia pracy $\mathrm{w}$ ziemię oraz kapitał (wartość zużycia wewnętrznego i amortyzacji). Wyniki zostały pokazane w tabelach 4-5 oraz na rysunkach 6-7. Nakłady ziemi na pełnozatrudnionego były mniej zróżnicowane niż w dwóch poprzednich przypadkach. Zarówno wartości współczynników Giniego, jak i współczynników zmienności były niższe. Zmalał zatem nieco obszar A na rysunku 6. Uzupełnienie do tych wyników załączono w tabeli 7. Wynika z niej, że najmniejsze nakłady ziemi na pełnozatrudnionego odnotowano na Malcie (2,1-2,5 ha), największe zaś w Wielkiej Brytanii (52,5-58,2 ha/AWU). Polskie rolnictwo opisywała w tym czasie wartość $6,4-7,5$ ha.

Tabela 4

Zróżnicowanie relacji czynnika ziemi na pełnozatrudnionego w rolnictwie w UE w latach 2005-2016

\begin{tabular}{|c|c|c|}
\hline Lata & Współczynnik Giniego & Współczynnik zmienności [\%] \\
\hline 2005 & 0,387 & 71,4 \\
\hline 2006 & 0,383 & 70,6 \\
\hline 2007 & 0,379 & 69,9 \\
\hline 2008 & 0,373 & 68,5 \\
\hline 2009 & 0,370 & 67,9 \\
\hline 2010 & 0,361 & 65,7 \\
\hline 2011 & 0,360 & 65,3 \\
\hline 2012 & 0,361 & 65,3 \\
\hline 2013 & 0,362 & 65,4 \\
\hline 2014 & 0,362 & 65,2 \\
\hline 2015 & 0,359 & 64,5 \\
\hline 2016 & 0,357 & 64,1 \\
\hline
\end{tabular}

Źródło: Obliczenia własne na danych Eurostatu i GUS.

Jednak w przypadku analizy nakładów kapitału na pełnozatrudnionego (tab. 5 i rys. 7), znowu powróciliśmy do znacznych różnic wartości w poszczególnych państwach UE. Zróżnicowanie to było podobne zbliżone do różnorodności wynagrodzeń pracy w rolnictwie. Krzywa Lorenza miała tu podobne odchylenie od linii egalitarnej i wyznaczała porównywalny obszar A. Można z nich wnioskować, że różnice w poziomie uzbrojenia pracy w kapitał skutkują różnicami w wydajności pracy i jej wynagradzania w poszczególnych państwach 


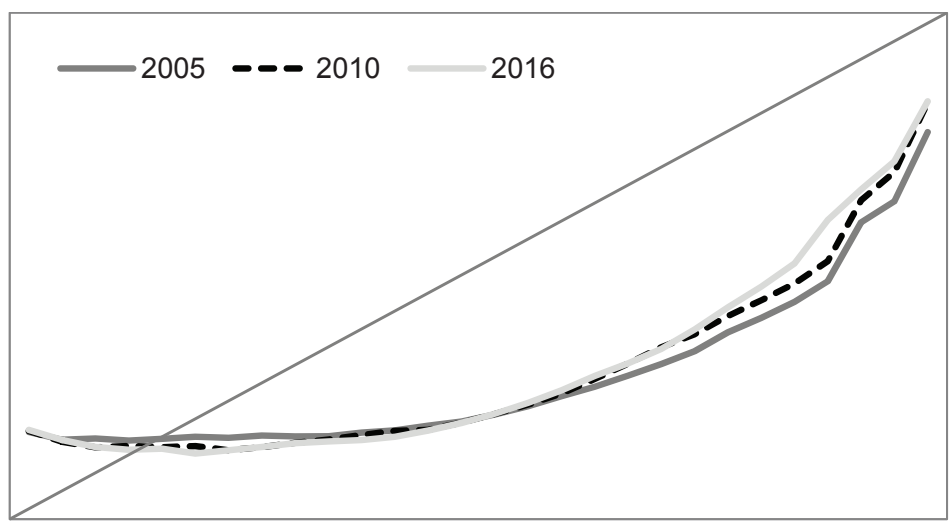

Rysunek 6

Zróżnicowanie nakładów ziemi na pełnozatrudnionego w rolnictwie UE - interpretacja graficzna współczynników Giniego

Źródło: Opracowanie własne.

\section{Tabela 5}

Zróżnicowanie relacji nakładów kapitału na pełnozatrudnionego AWU

\begin{tabular}{|c|c|c|}
\hline Lata & Współczynnik Giniego & Współczynnik zmienności [\%] \\
\hline 2005 & 0,473 & 91,7 \\
\hline 2006 & 0,479 & 93,8 \\
\hline 2007 & 0,481 & 94,8 \\
\hline 2008 & 0,482 & 95,4 \\
\hline 2009 & 0,488 & 96,8 \\
\hline 2010 & 0,483 & 96,0 \\
\hline 2011 & 0,488 & 98,4 \\
\hline 2012 & 0,487 & 97,6 \\
\hline 2013 & 0,483 & 96,5 \\
\hline 2014 & 0,475 & 94,8 \\
\hline 2015 & 0,467 & 94,1 \\
\hline 2016 & 0,466 & 93,6 \\
\hline
\end{tabular}

Źródło: Obliczenia własne na danych Eurostatu i GUS.

Wspólnoty. Szczegółowe dane na ten temat zamieszczono w tabeli 7. Wynika z niej, że do 2010 roku najniższe nakłady kapitału w przeliczeniu na 1 AWU miała Bułgaria. Jednak po 2010 roku to w polskim rolnictwie odnotowano najsłabsze uzbrojenie pracy w kapitał (rzędu 7611,2-7809,5 tys. euro/AWU). Niezmiennie natomiast najwyższe nakłady kapitału na jednostkę pracy cechowały rolnictwo duńskie (124623,8-170955,6 tys. euro/AWU). 


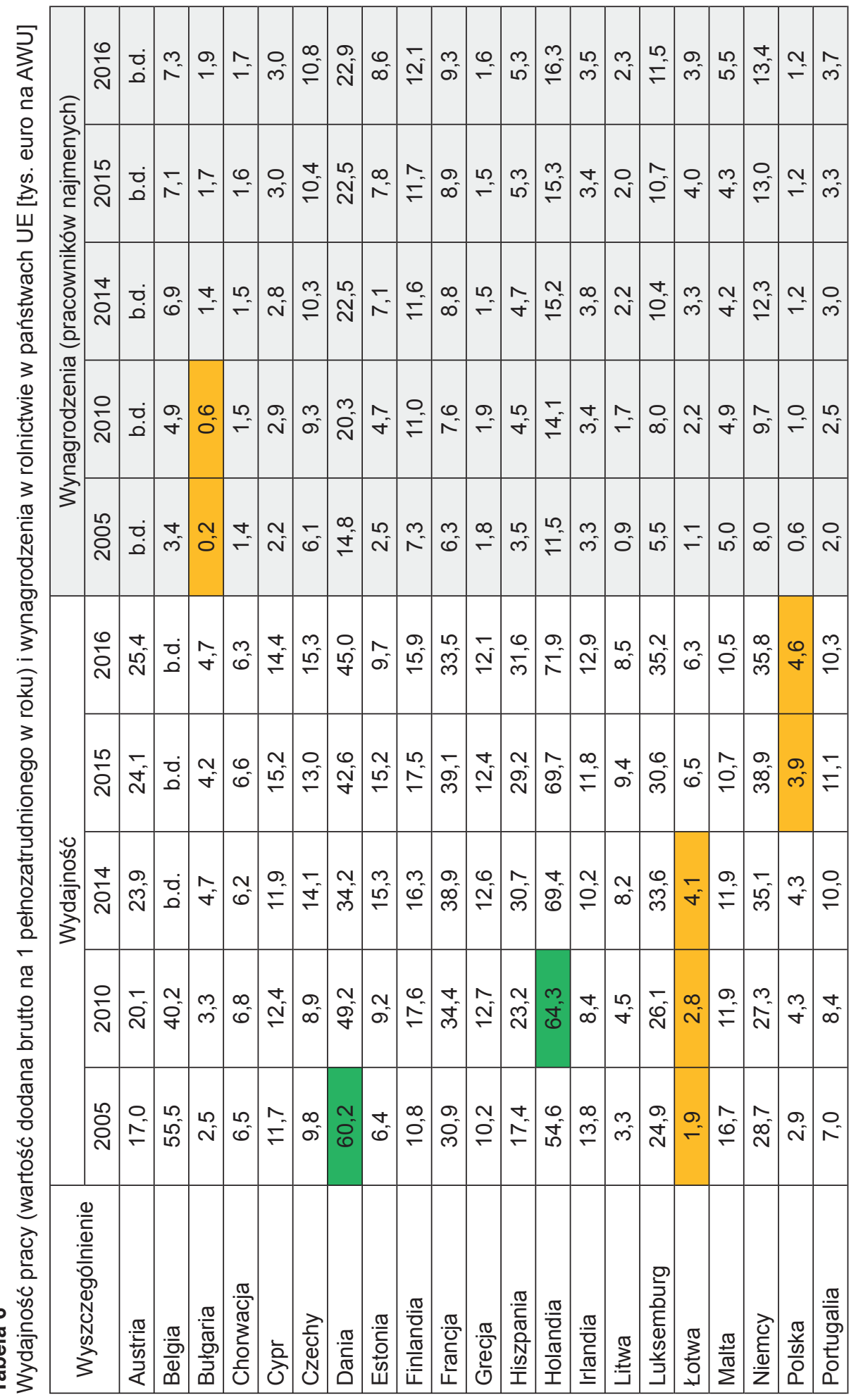




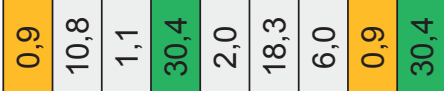

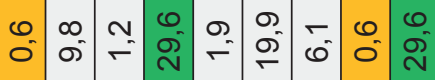

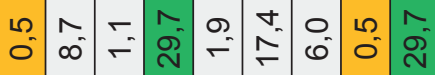

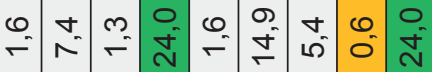

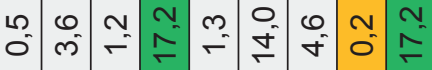

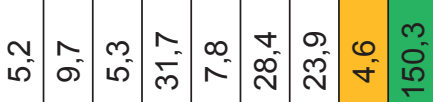

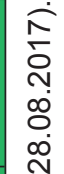

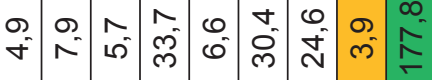

$\frac{\ddot{Q}}{\frac{\pi}{0}}$

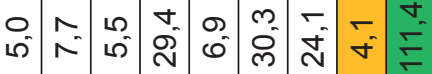

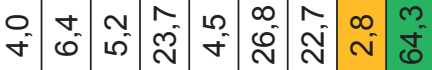

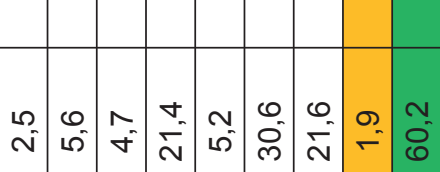

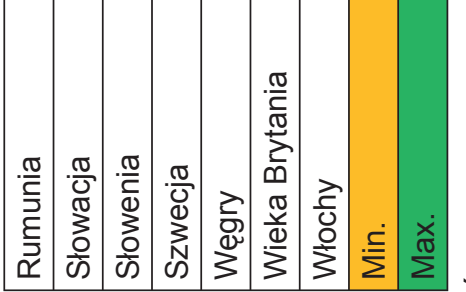

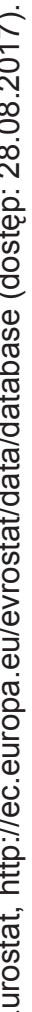




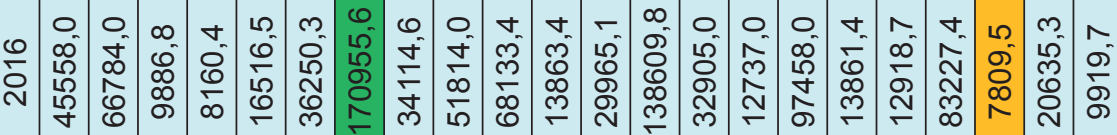

$\gtreqless$

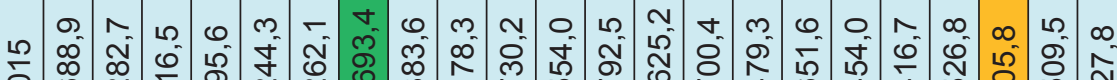

으

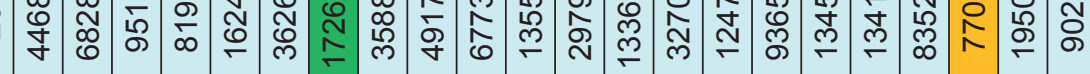

山

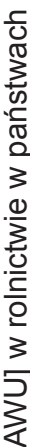

它

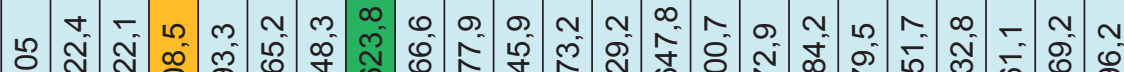

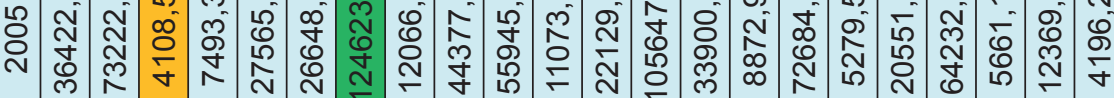

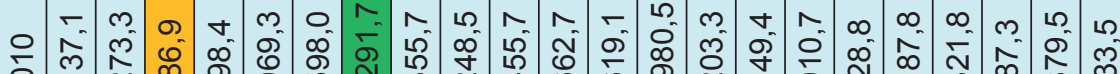

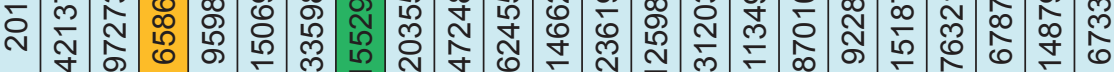

章

$\sum^{\infty}$

웅

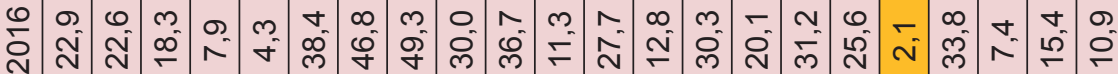

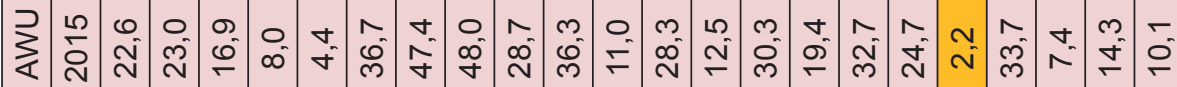
齐

妾

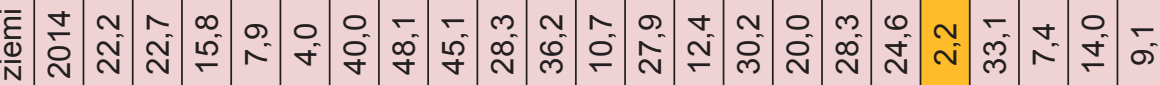

즌 장

$\frac{\frac{\pi}{0}}{\frac{\pi}{5}} \frac{\frac{\pi}{2}}{\frac{\pi}{2}}$

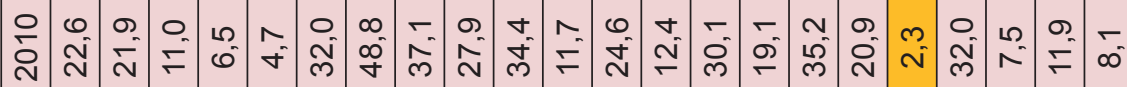

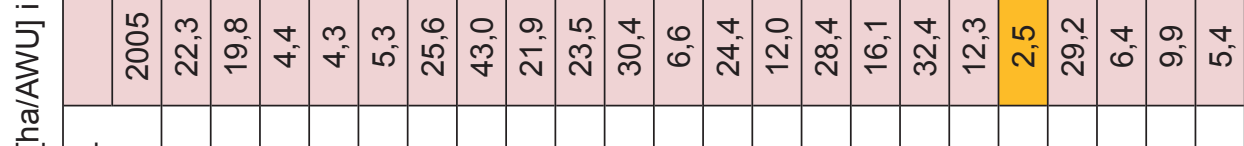

产 $\frac{1}{\overline{0}}$

$\sim \stackrel{N}{N}$ N

衣

$\frac{\pi}{\frac{\pi}{0}} \frac{\pi}{\frac{\pi}{2}}$

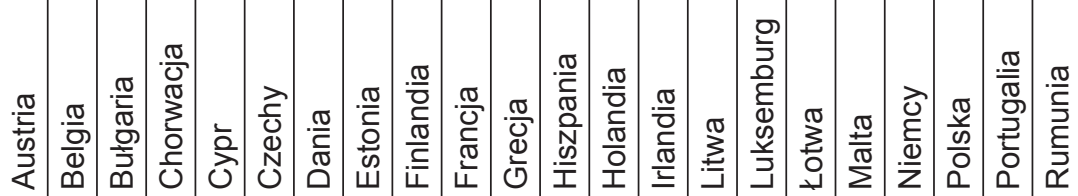




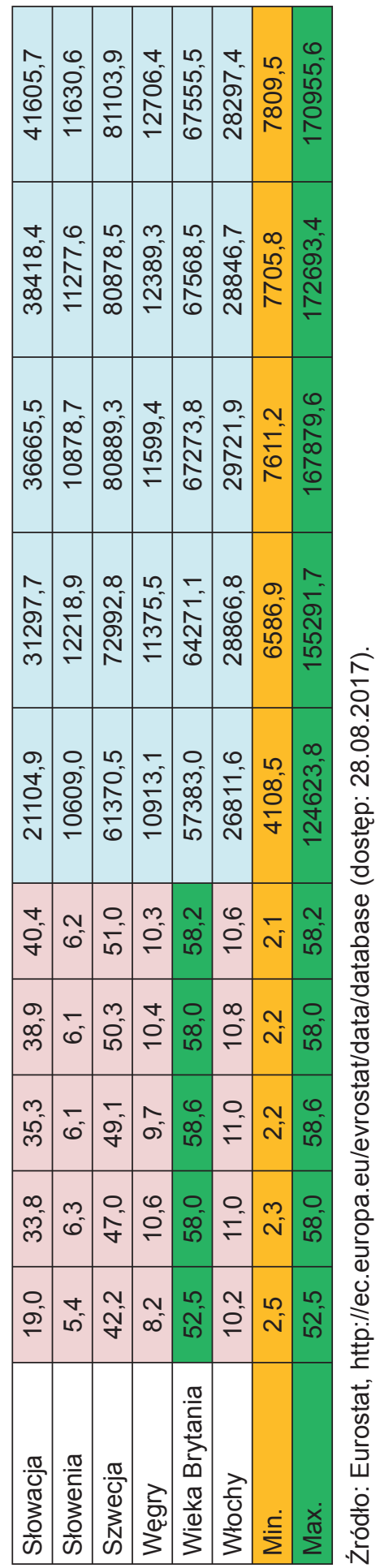




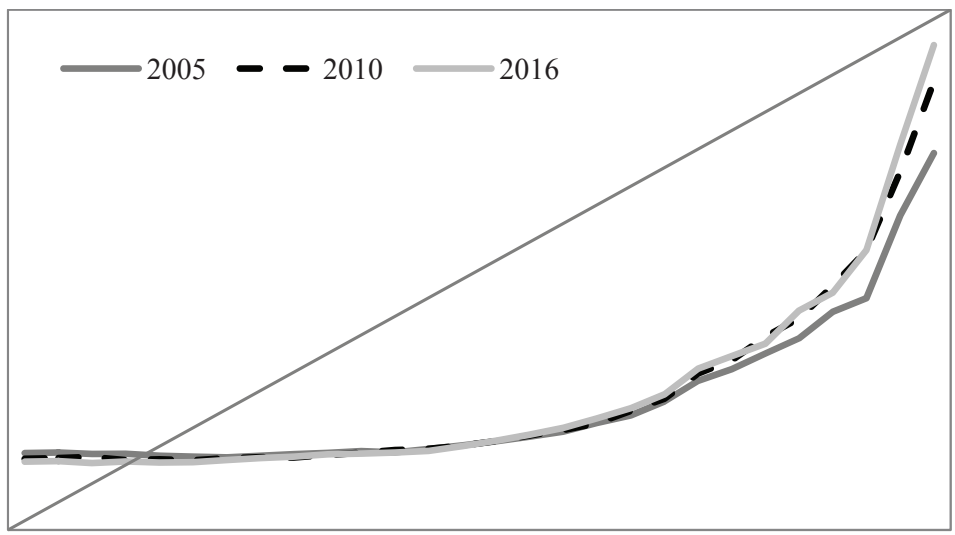

\section{Rysunek 7}

Zróżnicowanie nakładów kapitału na pełnozatrudnionego w rolnictwie UE - interpretacja graficzna współczynników Giniego

Źródło: Opracowanie własne.

\section{Podsumowanie}

Reasumując, w świetle analizowanych danych empirycznych można przyjąć, że największy poziom zróżnicowania wewnątrz państw UE dotyczył wydajności pracy w rolnictwie. Świadczą o nim wysokie wartości współczynników Giniego, duże odchylenie krzywej Lorenza od linii egalitarnej, jak również bardzo wysokie wartości współczynnika zmienności. Pojawiły się także różnice w poziomie wynagradzania pracy. Jednak były one nieco łagodniejsze. Współczynnik korelacji między wydajnością a wynagrodzeniem oscylował wokół $0,3 \mathrm{w}$ poszczególnych latach analizy i nie świadczył o silnej zależności obu tych zmiennych. Wskazywać to może na efekty polityki rolnej WPR w zakresie wyrównywania dochodów i niespełnianie warunków równowagi wspomnianweryfikowały w praktyceych w ujęciu analitycznym. Relatywnie najmniej zróżnicowane było uzbrojenie czynnika pracy w ziemię. Tutaj otrzymane wyniki wskazywały na łagodniejsze różnice między członkami Wspólnoty. Zróżnicowanie wynagrodzeń oraz poziomu uzbrojenia pracy w kapitał wykazywały podobne tendencje i zbliżona niejednorodność wewnątrz UE. Faktem jest, że państwa o relatywnie wyższym poziomie nakładów czynnika ziemi i kapitału w przeliczeniu na jednostkę AWU osiągały najlepszą wydajność pracy w rolnictwie i najlepiej tę pracę wynagradzały (Dania, Belgia, Holandia). Pozytywne weryfikowały w praktyce analizowane w niniejszej pracy ujęcie analityczne bazujące na fundamentalnych zależnościach w ekonomii. 


\section{Literatura}

ARiMR, Średnia powierzchnia gospodarstwa, http://www.arimr.gov.pl/pomoc-krajowa/srednia-powierzchnia-gospo-darstwa.html (dostęp: 27.09.2017).

BEAR-NAWROCKA A., MARKIEWICZ N., 2012: Procesy konwergencji/dywergencji $w$ zakresie wydajności pracy w rolnictwie Unii Europejskiej - analiza regionalna, Journal of Agribusiness and Rural Development 3(25), 13-23.

CZYŻEWSKI A., KRYSZAK Ł., 2016: Współzależności międzygatęziowe w sektorze rolnym $w$ świetle modelu input-output a poziom finansowego wsparcia rolnictwa $w$ wybranych krajach, Zeszyty Naukowe Szkoły Głównej Gospodarstwa Wiejskiego w Warszawie. Problemy Rolnictwa Światowego 16 (31), 2, 55-65.

DĄBROWSKA J., 2017: Bez wzrostu wydajności gospodarka wyhamuje, Puls biznesu z dn. 18.07.2017, https://www.pb.pl/bez-wzrostu-wydajnosci-gospo-darka-wyhamuje866681 (dostęp: 10.08.2017)

DEBERTIN D.L., 1986: Agricultural Production Economics, McMilan PCompany, New York.

DUCZKOWSKA-MAŁYSZ K., 2015: Jak zreformować polskie rolnictwo?, audycja radiowa w TOK FM, wywiad z dn. 5.02.2015.

GADOMSKI W., 2015: Najpierw wydajność, potem wynagrodzenia, Obserwator Finansowy, https:/www.obserwatorfinansowy.pl/tematyka/ma-kroekonomia/najpierw-wydajnoscpotem-wynagrodzenia/ (dostęp: 30.08.2017).

GOŁAŚ Z., 2010a: Czynniki kształtujace wydajność pracy w przedsiębiorstwach przemystu spożywczego, Zagadnienia Ekonomiki Rolnej 4, 30-50.

GOŁAŚ Z., 2010b: Wydajność i dochodowość pracy w rolnictwie w świetle rachunków ekonomicznych dla rolnictwa, Zagadnienia Ekonomiki Rolnej 3, 19-42.

GOŁAŚ Z., KOZERA M., 2004: Wydajność pracy polskich gospodarstw rolnych $w$ aspekcie integracji z Uniq Europejska, Roczniki Naukowe SERIA 6, 1, 62-67.

GOŁAŚ Z., KOZERA M., 2008: Strategie wydajności pracy w gospodarstwach rolnych, Journal of Agribusiness and Rural Development 1 (7), 61-71.

GÓRAL J., 2017: W Polsce rolnictwo opłaca się od 50 hektarów, Obserwator Finansowy, https://www.obserwatorfinansowy.pl/forma/rotator/w-polsce-rolnictwo-oplaca-sie-od50-hektarow/ (dostęp: 25.05.2017).

GUS, 2017: Rocznik statystyczny rolnictwa, Zakład Wydawnictw Statystycznych, Warszawa, 42-248.

http://ec.europa.eu/eurostat/web/products-datasets/product?code=tipsna70 (dostęp: 18.05.2017).

http://stats.oecd.org/Index.aspx?DatasetCode=LEVEL (dostęp: 18.05.2017).

https://data.oecd.org/lprdty/gdp-per-hour-worked.htm (dostęp: 18.08.2017).

KAKWANI N.CH., 1980: Income inequality and poverty: methods of estimation and policy applicationsOxford University Press, New York.

KOŁODZIEJCZAK M., 2008a: Efektywność wykorzystania zasobów pracy i ziemi w rolnictwie Unii Europejskiej, Roczniki Naukowe SERiA, 10, z. 1, 176-181.

KOŁODZIEJCZAK M., 2008b: Zróżnicowanie regionalne rolnictwa $w$ Polsce $i w$ Niemczech, Zeszyty Naukowe Szkoły Głównej Gospodarstwa Wiejskiego, Problemy Rolnictwa Światowego 4 (19), 270-280. 
KOŁODZIEJCZAK M., 2014: Efektywność wykorzystania czynników produkcji w rolnictwie polskim i niemieckim w latach 2004-2012, Roczniki Naukowe Ekonomii Rolnictwa i Rozwoju Obszarów Wiejskich 101, 2, 55-63.

KOŁODZIEJCZAK M., MRÓWCZYŃSKA-KAMIŃSKA A., 2008: Efektywność wykorzystania nakładów pracy $w$ rolnictwie polskim na tle Unii Europejskiej, Studia i Prace WNEiZ, Uniwersytet Szczeciński, 145-152.

KOSMALSKI R., 2010: Zróżnicowanie poziomu wydajności pracy i jego przyczyny w polskich województwach w latach 1998-2008, Studia Regionalne i Lokalne 3 (41), 100-114.

KUSZ D., MISIAK T., 2017: Wpływ technicznego uzbrojenia pracy i postępu technicznego na wydajność pracy w rolnictwie, Roczniki Naukowe SERiA 19, 2, 145-150.

KUŹMAR S., 2015: Zróżnicowanie regionalnej wydajności pracy w Polsce, Współczesne Problemy Ekonomiczne. Globalizacja. Liberalizacja. Etyka 11, 137-147.

MACIEJEWICZ P., 2016: Polska wieś nie żyje z roli. A rolnictwo mamy niemal najmniej wydajne w Europie, Gazeta Wyborcza, z dn. 16.06.2016.

MRÓWCZYŃSKA-KAMIŃSKA A., 2012: Wydajność pracy $w$ gospodarce żywnościowej w Polsce i Niemczech, Roczniki Ekonomii Rolnictwa i Rozwoju Obszarów Wiejskich 99, 2, 69-75.

NOWAK A., 2011: Zmiany wydajności rolnictwa Polski i innych krajów Unii Europejskiej, Zeszyty Naukowe Szkoły Głównej Gospodarstwa Wiejskiego, Problemy Rolnictwa Światowego 11 (26), 1, 130-139.

NUŻYŃSKA I., WILKIN J., (red.). 2016: Polska wieś 2016. Raport o stanie wsi. FDPA, Wydawnictwo Scholar, Warszawa, 19-36.

POCZTA W., KŁODZIEJCZAK M., 2004: Potencjat produkcyjny rolnictwa polskiego i efektywność gospodarowania w aspekcie integracji z Uniq Europejska, Wydawnictwo AR, Poznań, $21-46$.

POCZTA W., KŁODZIEJCZAK M., 2008: Regionaldifferenzierung der Landwirtschaftseffektivität in der Europäischen Union, Journal of Agribusiness and Rural Development 1 (7), 109-121.

REMBISZ W., 2016: Relacja wynagrodzenia i wydajności czynnika pracy w rolnictwie na tle gospodarki narodowej i jej sektorów w Polsce w okresie 2005-2012, Wieś i Rolnictwo 2 (171), 41-57.

REMBISZ W. SIELSKA A., 2012: Mikroekonomiczna funkcja produkcji, Vizja\&It Press, $37-51$.

REMBISZ W., SIELSKA A., 2015: Wydajność pracy a dochody producentów rolnych, Zeszyty Naukowe Uniwersytetu Ekonomicznego w Katowicach 235, 208-221.

WASILEWSKI M., WASILEWSKA A., 2011: Koszty wynagrodzeń pracy najemnej w gospodarstwach indywidualnych $w$ zależności od typu rolniczego. Ekonomika i Organizacja Gospodarki Żywnościowej 91, 229.

WĄSOWICZ J., 2013: Sektorowe zróżnicowanie wydajności pracy w polskiej gospodarce, Studia Ekonomiczne Uniwersytetu Ekonomicznego w Katowicach 160, 2013, 190-198.

WILKIN J., NUŻYŃSKA I., 2016: Raport o stanie wsi. Polska wieś 2016, FDPA, Wydawnictwo Scholar, Warszawa, 11-105.

WŁODARCZYK J., 2013: Nierówności dochodowe w Polsce wedtug rozkładów Pareto i Boltzmanna-Gibbsa, Problemy Gospodarki Rynkowej: Polska i Świat 130, 76-87.

ZEGAR J.S., 2008: Dochody w rolnictwie w okresie transformacji i integracji europejskiej, IERiGŻ-PIB, Warszawa. 


\section{Abstrakt}

Celem artykułu była analiza porównawcza wydajności pracy w rolnictwie w państwach Unii Europejskiej. Z danych Eurostat-u wynika, szybszy przyrost wydajności pracy dotyczył krajów UE-12, jednak „startowały” one ze znacznie niższego poziomu. Stąd wyniki te nadal wymagają dalszej poprawy i dalszego doganiania (catching up) państw UE-15 (tzw. „starej Unii”). W świetle analizowanych oraz przeprowadzonych badań empirycznych wydajność pracy w polskim sektorze rolnym zaliczono do najniższej w całej UE. Potwierdził to również przegląd literatury oraz wnioski płynące z badań licznych autorów. W efekcie pochodną tego są niższe wynagrodzenia. Analiza czynników determinujących w ujęciu teoretycznym wydajność pracy pokazała potencjalne źródła wzrostu tej wielkości.

Słowa kluczowe: wydajność pracy, wynagrodzenia, analiza porównawcza, współczynnik Giniego, rolnictwo, Unia Europejska

\section{Remunerations and labour productivity in agriculture against a background of other european union countries}

\section{Abstract}

The aim of the article was to compare the agricultural work performance in the European Union countries. According to Eurostat data, faster labor efficiency growth was observed in the EU-12 countries, but they "started" at a much lower level. Hence, these results still require further improvement and catching up of EU-15 ("old Union") countries. Labor efficieny (work performance) in the Polish agricultural sector is among the lowest ones in the EU. In the light of the empirical studies, labor efficiency in the Polish agricultural sector has been ranked among the lowest ones in the EU. This was also confirmed by the review of the literature and the conclusions of numerous authors. As a result, the derivative of this are lower wages. Analysis of factors, determining the theoretical performance of labor, showed potential sources of growth of this size.

Key words: labor efficiency, salary, comparative analysis, Gini coefficient, agriculture, European Union 